\title{
The Inclusion of a Supercritical Fluid Extract, Obtained From Honey Bee Pollen, in the Diet of Gilthead Sea Bream (Sparus aurata), Improves Fish Immune Response by Enhancing Anti-oxidant, and Anti-bacterial Activities
}

OPEN ACCESS

Edited by:

Andres M. Perez, University of Minnesota Twin Cities,

United States

Reviewed by:

Mahmoud A. O. Dawood, Kafrelsheikh University, Egypt Fotini Kokou,

Wageningen University \&

Research, Netherlands

Abdelkarim Mahdhi,

University of Monastir, Tunisia

*Correspondence.

Giovanni Piccolo giovanni.piccolo@unina.it

Concetta Maria Messina

concetta.messina@unipa.it

Specialty section:

This article was submitted to Animal Nutrition and Metabolism,

a section of the journal

Frontiers in Veterinary Science

Received: 02 January 2020 Accepted: 10 February 2020

Published: 25 February 2020

Citation: Messina CM, Panettieri V, Arena $R$,

Renda G, Espinosa Ruiz C,

Morghese M, Piccolo G, Santulli A and Bovera $F$ (2020) The Inclusion of a

Supercritical Fluid Extract, Obtained From Honey Bee Pollen, in the Diet of Gilthead Sea Bream (Sparus aurata), Improves Fish Immune Response by Enhancing Anti-oxidant, and Anti-bacterial Activities.

Front. Vet. Sci. 7:95.

doi: 10.3389/fvets.2020.00095
Concetta Maria Messina ${ }^{1 *}$, Valentina Panettieri ${ }^{2}$, Rosaria Arena $^{1}$, Giuseppe Renda ${ }^{1}$, Cristobal Espinosa Ruiz ${ }^{1}$, Maria Morghese ${ }^{1}$, Giovanni Piccolo ${ }^{2 *}$, Andrea Santulli ${ }^{1,3}$ and Fulvia Bovera ${ }^{2}$

${ }^{1}$ Laboratory of Marine Biochemistry and Ecotoxicology, Department of Earth and Sea Sciences, University of Palermo, Palermo, Italy, ${ }^{2}$ Department of Veterinary Medicine and Animal Production, University of Naples Federico II, Naples, Italy, ${ }^{3}$ Institute of Marine Biology, Consorzio Universitario Della Provincia di Trapani, Trapani, Italy

In the present study, the immune-stimulatory effect of two levels of honey bee pollen (5 and 10\%, P5 and P10 treatment, respectively) and its supercritical fluid extract (0. 5 and 1\%, E0.5 and E1, respectively) included in the diet, was tested in gilthead seabream (Sparus aurata). The in vivo trial was preceded by the evaluation of antioxidant properties of three different bee pollen extracts obtained by water, ethanol $80 \%$, and Supercritic Fluids Extraction (SFE). The preliminary evaluation attested that the SFE showed the lowest extraction yield (10.47\%) compared to ethanol 80\% (48.61\%) and water (45.99\%). SFE extract showed good antioxidant properties with high polyphenol content (13.06 mg GAE/g), radical scavenging activity $(3.12 \mathrm{mg} / \mathrm{ml})$, reducing power (38.68 $\mathrm{mg} / \mathrm{mL}$ EC50). On the contrary, the water extract showed the significantly lowest polyphenol content ( $2 \mathrm{mg} \mathrm{GAE} / \mathrm{g} ; P<0.05$ ). The results of in vivo trial demonstrate that the diets supplemented with SFE bee pollen extract had a stimulatory effect on fish serum immunity, respect to the inclusion of raw pollen, this latter revealing some inhibitory effects in the immune response, such a decrease of serum peroxidase and lysozyme activities, particularly in P10 group significantly different $(P<0.05)$ from the control group. On the contrary, serum peroxidase, protease, antiprotease, were significantly increased in fish fed the diets supplemented with supercritical fluid extract, respect to the fish fed on control and on diets supplemented with 5 and $10 \%$ of raw pollen. For what concerns the bactericidal activity against Vibrio harveyii, all the treatments containing bee pollen regardless of the type showed their serum bactericidal activity significantly increased with respect to the control groups $(p<0.05)$. Given its high antioxidant properties, the absence of toxic solvents and the positive action carried out on improving the humoral response in gilthead seam bream, honey bee pollen SFE extract can be taken into account in the formulation of fish feeds.

Keywords: honey bee pollen, supercritical fluid extraction, antioxidants, immune-stimulation, Sparus aurata 


\section{INTRODUCTION}

Recently, there has been an increased interest on using plant, medicinal herbs and others compounds as natural immunostimulants, able to enhance the disease resistance in cultured fish (1). Products of vegetable origin seem to represent a very promising source of bioactive molecules, being both easily available, cheap, and biocompatible (2). Some plants, certain parts of them or the extracts, can improve fish health enhancing both the innate and the adaptive immune response, against bacteria, viruses, or parasites $(1,3)$. This action is represented by the modulation of some enzymes or complexes such as lysozyme, complement, anti-protease, peroxidase, or by the ability to improve some activities as respiratory burst, phagocytosis, antibody production, antioxidant, anti-stress, anti-helminthic, anti-protozoa, anti-fungal, anti-bacterial, and anti-viral (1-4). The use of natural compounds due to their biocide activities represents a promising substitute to the use of the antibiotics and vaccines which are commonly applied in aquaculture to control fish and molluscs diseases $(1,2)$. In addition, many of these vegetable-derived products have other positive benefits for fish, including enhanced growth, increased weight, appetite stimulation, and they also have the ability to facilitate the sexual maturation of farmed species, while acting as anti-stress and anti-infection agents, including many other health benefits (4).

Honey bee pollen (HBP), in particular, is becoming increasingly popular as functional food for human consumption as a potential source of energy and for its high content of compounds with positive health effects, such as essential amino acids, antioxidants, vitamins, and lipids $(5,6)$. Pollen preparations are distributed worldwide for dietary scope and as diet integrators. In the USA bee pollen is described by the Dietary Supplement Health and Education Act of 1994 as Dietary Supplement employed to supplement the diet by increasing the total dietary intake (7). The pollen collected by bees contains nutritionally essential components such as carbohydrates, proteins, amino acids, vitamins, mineral substances and trace elements, but also lipids, such as fatty acids, sterols, and several other bioactive compounds (6). Polyphenol substances, mainly flavonoids, are considered, among the ingredients, the principal biomarkers of quality, and may be used for the establishment quality standards for health control of commercially distributed pollen preparations and in relation to their nutritional-physiological properties (7). The bioactive quality of bee pollen decreases over time, and that conditioning carried out on fresh pollen before storage affects its nutritional and functional value $(6,8)$. In order to extend the shelf life of bee pollen and avoid rapid fermentation and deterioration, a dehydration process (artificial drying) is necessary, since its composition has a high level of moisture. In recent years, the growing interest in the extraction and determination of these beneficial bee pollen compounds, has been confirmed by the number of published researches on this topic (6).

For the extraction of natural compounds, solvents with different polarity, from water, to hydro-alcoholic solution are used $(9,10)$. The antioxidant activity of the extracts and their extraction yield are influenced by the polarity of the solvent.
Therefore, the use of different solvents is related to the nature of the polyphenols in the samples (11). For the extraction of many compounds, among these also phenolic ones, the supercritical fluid extraction (SFE) technology is applied. This alternative and green method is often put in comparison to traditional extraction methods with different solvents (ethanol and water), in terms of yield and product quality evaluated by the antioxidant activity of the extracts (10). Today, bee pollen has been used for improving chicken, mammal, and fish growth (12-14). However, there are few studies on the use of bee pollen and its extract to improve welfare and immunity of fish against fish pathogens. Our recent study on meager (Argyrosomus regius) demonstrated a negative effect of the addition of raw pollen in the diet on growth, diets digestibility, intestinal traits, and biochemical markers related to health and stress (15), probably due to the structure of bee pollen grains. In view of these results, in the present study on gilthead sea bream, we wanted to verify whether these negative effects could be overcome by the inclusion in the feed of the bioactive fractions previously extracted from pollen, using advanced techniques such as SFE, which does not involve the use of solvents.

Therefore, the aim of the present study was to evaluate the effect of the inclusion of raw and SFE extracted pollen on the immunity response of Sparus aurata, one of the most important fish species for Mediterranean aquaculture, so that the results emerging from the trial could potentially found practical applications. A preliminary evaluation of the antioxidants properties of HBP extracts, obtained by chemical and SF extractions, was done. Among immune-related parameters we focused on the activity of different enzymes present in the serum of sea bream (peroxidase, protease, anti- protease, and lysozyme), which are considered as good descriptors for health status in marine organisms $(16,17)$. In addition, bactericidal activity of $S$. aurata serum against two pathogenic Vibrio species were evaluated.

\section{MATERIALS AND METHODS}

\section{Extraction With Solvents}

About $2 \mathrm{~kg}$ of HBP from chestnut, purchased from a local organic farm located in the city of Naples (Napoli, Italy), and collected in about 1 week, were utilized for the trials. For the extractions ethanol $80 \%$ and water $(1: 10 \mathrm{w} / \mathrm{v})$ were used $(10,18)$. The materials were then homogenized according to a consolidated protocol (19-22). The matrices extracted were centrifuged and then filtered (Whatman ${ }^{\circledR}$ qualitative filter paper, Grade $93-10 \mu \mathrm{m}$, Merck KGaA Darmstadt, Germany) and freeze-dried $(10,18)$.

\section{Supercritical Fluid Extraction (SFE)}

A supercritical extraction unit (SFE System model HELIX, Applied Separations Allentown, PA, USA) was used.

Before the dynamic extraction, a static treatment with SC$\mathrm{CO}_{2}$ was carried out to break the cell walls of bee pollen (5). Dynamic extraction was conducted on dried bee pollen following the method applied by $\mathrm{Xu}$ et al. (5) with some modifications. For each extraction the dried powder and hydroscopic dispersing 
agent (Applied Separations, Allentown, PA, USA) were mixed and placed in the extraction vessel, the unit was pressurized, and dynamic extraction was carried out at pre-established conditions of temperature and pressure with a $\mathrm{CO}_{2}$ and a co-solvent flow for $2 \mathrm{~h}$. An additional extraction hour was applied changing the $\mathrm{CO}_{2}$ and co-solvent flow.

The obtained extract was stored at $-20^{\circ} \mathrm{C}$ and subsequently extracts were dried.

\section{Characterization of the Antioxidant Power of HBP Extracted by the Three Different Extraction Methods \\ Total Polyphenols Contents}

Total phenolics were analyzed using Folin-Ciocalteu's assay. Gallic acid was used as standard and results were expressed as mg of gallic acid equivalents (GAE) per g of extract of bee pollen $(10,22,23)$. Each sample was analyzed in triplicate.

\section{DPPH Radical Scavenging Activity}

The DPPH (1,1-diphenyl-2-picryhydrazyl) radical scavenging activity was assessed using the method described by Bernatoniene et al. (24) slightly modified by Messina et al. (22): $400 \mu \mathrm{L}$ of various concentrations of the extracts was replenished up to $2.0 \mathrm{~mL}$ with $0.1 \mathrm{mM}$ DPPH radical solution in ethanol.

After $30 \mathrm{~min}$ of incubation the absorbance was read against the blank at $517 \mathrm{~nm}$. Gallic acid was employed as the reference. Inhibition of DPPH free radical in percent (I\%) was calculated as given below (25):

$$
I \%=1-\left(\frac{\text { Asample }}{\text { Ablank }}\right) * 100
$$

where Ablank is the absorbance of the control reaction, and Asample is the absorbance of the test sample. The results are expressed as IC 50, mg/mL (26).

\section{Reducing Power}

The power of the extracts to reduce iron (III) was determined according to the method of Oyaizu (27). Three hundred microliter of sample solutions at different concentrations were mixed with phosphate buffer and potassium ferricyanide $1 \%$; the mixture was incubated at $50^{\circ} \mathrm{C}$ for $20 \mathrm{~min}$. Three hundred microliter of trichloroacetic acid (10\%) was added to the mixture, prior to centrifugation. The upper layer of solution $(300 \mu \mathrm{L})$ was mixed with distilled water $(300 \mu \mathrm{L})$ and $\mathrm{FeC}_{13}(600 \mu \mathrm{L}, 0.1 \%)$, and the absorbance was measured at $700 \mathrm{~nm}$ against gallic acid as standard. The results are expressed as EC50, $\mathrm{mg} / \mathrm{mL}(25,28)$.

\section{Fish and Experimental Conditions}

The trial was performed in the experimental aquaculture facility of the Department of Veterinary Medicine and Animal Production of Federico II University (Naples, Italy) in respect of the Directive 2010/63/EU and was approved by the University Federico II Ethical Committee and authorized by the Italian Ministry of Health, authorization n. 651/2017-PR; it lasted 30 days and was carried out in an indoor marine water recirculating system (Italian Ministry of Health authorizations n. 78/2013$\mathrm{A}$ and 25/2019-UT) using 90 gilthead sea breams (294.7 \pm
12.8 g average initial body weight-IBW) supplied by a local fish farm. The system assured control of water temperature and was equipped with mechanical sand filter, biological filter and UVA sterilization lamp apparatus.

The trial started after a 15 days adaptation period of the fish to the experimental conditions. The water quality parameters were as follows: daily water renewal $<1 \%$, artificial day length $12 \mathrm{~h}$, temperature $22 \pm 1.5^{\circ} \mathrm{C}$, salinity: $33.0 \pm 2.0 \mathrm{~g} / \mathrm{l}$, dissolved oxygen $6.5 \pm 1.1 \mathrm{mg} / \mathrm{l}, \mathrm{pH} 7.9 \pm 0.5$, total ammonia nitrogen $<0.3 \mathrm{mg} / \mathrm{l}$, nitrite $<0.01 \mathrm{mg} / \mathrm{l}$, nitrate $<38 \mathrm{mg} / \mathrm{l})$.

On a daily basis, water temperature with a mercury thermometer, $\mathrm{pH}$ with an Orion digital $\mathrm{pH}$ meter and dissolved oxygen with an oxygen meter (WTW, OXI 330, Weilheim, Germany) were measured daily.

Bi-weekly, total ammonia nitrogen $(\mathrm{N}-\mathrm{NH} 3)$, nitrite-nitrogen $\left(\mathrm{N}-\mathrm{NO}_{2}\right)$ and nitrate nitrogen $\left(\mathrm{N}-\mathrm{NO}_{3}\right)$ were determined by colorimetric methods, using commercial kits and a spectrophotometer (Hanna Instruments, C-203, Leighton Buzzard, UK).

\section{Fish Diets}

Fish were randomly distributed in 15 fiberglass 2201 tanks (6 fish per tank) and were fed 5 isoenergetic and isoproteic diets. Each diet was randomly assigned to 3 tanks: a control diet; two diets in which HBP was included at 5\% (P5) and at $10 \%$ (P10) and two diets in which HBP extract, obtained by SFE, was included at $0,5 \%$ (E 0.5$)$ and at $1 \%$ (E1). The two pollen inclusion levels were chosen in order to have the same content of total polyphenols both in diets containing raw pollen (P5 and P10) and in diets containing the SFE extracts (E0.5 and E1). The diets were formulated to meet nutrient requirements of gilthead sea bream $(29,30)$.

The ingredients and chemical composition of the experimental diets are reported in Tables 1, 2, respectively. The diets were physically constituted at the laboratories of the Department of Veterinary Medicine and Animal Production, Napoli Federico II University (Naples, Italy). The HBP was finely chopped, mixed with $10 \mathrm{ml}$ of water to create a paste, then mixed in fish oil and incorporated into the mixture. For E 0.5 and E1 diets, the extract was dissolved initially in $10 \mathrm{ml}$ of fish oil, then incorporated into the mixture. Before the final mixing, all ingredients were ground through a $0.5 \mathrm{~mm}$ sieve, then water was added, and the mixture was pelleted through a $3 \mathrm{~mm}$ dye using a meat-grinder (Bosh mod. MFW68660, Germany). The diets were then dried in a ventilated oven at a temperature of $40^{\circ} \mathrm{C}$ for $24 \mathrm{~h}$. This temperature was chosen as it is very similar to the temperature maintained in the hive $\left(34.6^{\circ} \mathrm{C}\right.$ on average $)$ in order to preserve the pollen quality. The feeds were stored at $4^{\circ} \mathrm{C}$ until use. Each diet was administered twice a day (09:00 and 16:00 h), 7 days per week. Feeds were administered at $1 \%$ of the average body weight. At the end of the trial, all the fish were individually weighted and final weight and FCR were group/tank determined.

\section{Sampling}

After 30 days, on the day of the sampling, three fish per tank (336.2 $\pm 11.4 \mathrm{~g}$ average final body weight-FBW) were euthanized (over anesthesia (MS222-Tricain Metansulphonate at 
TABLE 1 | Ingredients of control diets provided to Sparus aurata $(\mathrm{g} / \mathrm{Kg})$.

\begin{tabular}{lc}
\hline Ingredients & Control \\
\hline Soy bean meal & 240.0 \\
Fish meal & 210.0 \\
Corn gluten & 190.0 \\
Fish oil & 160.0 \\
Gelatinized starch & 100.0 \\
Wheat gluten & 80.0 \\
Mineral & 10.0 \\
Vitamins & 10.0
\end{tabular}

The experimental diets (P5, P10, E0.5, and E1) were obtained subtracting from the premixed control diet an equivalent quantity to that of the substance to be added (50 and $100 \mathrm{~g}$ of honey bee pollen HBP were added to the diets P5 and P10; 5 and $10 \mathrm{~g}$ of SFE from HBP were added to the diets EO.5 and E1).

TABLE 2 | Chemical composition (\% as feed) of experimental diets provided to Sparus aurata (diets P5 and P10: inclusion of honey bee pollen HBP at 5 and $10 \%$; diets E0.5 and E1: inclusion of SFE from HBP at 0.5 and 1\%).

\begin{tabular}{lccccc}
\hline & Control & P5 & P10 & E0.5 & E1 \\
\hline Dry matter & 88.94 & 88.19 & 87.63 & 88.43 & 88.62 \\
Ash & 5.5 & 4.99 & 4.35 & 4.71 & 4.51 \\
Crude protein & 39.78 & 39.92 & 38.26 & 38.91 & 39.46 \\
Ether extract & 17.85 & 17.25 & 17.15 & 17.75 & 17.15 \\
Crude fibers & 7.17 & 7.54 & 8.63 & 7.37 & 7.62 \\
\hline
\end{tabular}

$250 \mathrm{mg} / \mathrm{L}$ dosage) and their weight and length were measured. Immediately, blood was collected from the caudal vessel via $5 \mathrm{ml}$ sterile syringes. Blood samples were collected in tubes with separator gel and are left to clot at $4^{\circ} \mathrm{C}$ for $4 \mathrm{~h}$. Serum were collected after centrifugation $\left(10,000 \mathrm{rpm}, 10 \mathrm{~min}, 4^{\circ} \mathrm{C}\right)$ and stored at $-80^{\circ} \mathrm{C}$.

\section{Serum Immune Parameters Peroxidase Activity}

The peroxidase activity in serum of sea bream fed the different diets, was measured, according to Quade and Roth (31) by oxidation of 3,3',5,5'-Tetramethylbenzidine (TMB). Briefly, $5 \mu \mathrm{L}$ of serum were diluted with Hanks's buffer (HBSS) without $\mathrm{Ca}^{+2}$ or $\mathrm{Mg}^{+2}$ to a final volume of $50 \mu \mathrm{L}$ in a flat-bottomed 96 -well plate. Were added $100 \mu \mathrm{L}$ of $10 \mathrm{mM}$ TMB with 0.025 of $30 \%$ $\mathrm{H}_{2} \mathrm{O}_{2}$, as substrate, and the color change reaction was stopped by adding $50 \mu \mathrm{L} 2 \mathrm{M} \mathrm{H}_{2} \mathrm{SO}_{4}$. The $\mathrm{OD}$ was read at $450 \mathrm{~nm}$ in a plate reader. Sample without serum were used as blank, and the OD values were subtracted for each sample value. One unit was defined as the amount producing an absorbance change of 1 , and the activity expressed as $\mathrm{U} \mathrm{mL}^{-1}$ for the serum samples. All samples were analyzed in triplicate.

\section{Protease Activities}

Protease activity was quantified, according to the method described by Ross et al. (32), using the azocasein hydrolysis assay. Ten microliter of serum were incubated with $100 \mu \mathrm{L}$ of ammonium bicarbonate buffer and $125 \mu \mathrm{L}$ of $2 \%$ azocasein
(Sigma Aldrich) in sterile eppendorfs overnight (at RT and in agitation). The reaction was stopped by adding $250 \mu \mathrm{L}$ of $10 \%$ trichloroacetic acid (TCA). The mixtures were centrifuged $(6,000 \mathrm{~g}, 5 \mathrm{~min}), 100 \mu \mathrm{L}$ of the supernatants transferred to a flatbottomed 96-well plate, and $100 \mu \mathrm{L}$ of $1 \mathrm{~N} \mathrm{NaOH}$ added. The OD was read at $450 \mathrm{~nm}$ using a plate reader. For the positive controls ( $100 \%$ of protease activity), the serum, was replaced by trypsin ( $5 \mathrm{mg} \mathrm{mL}^{-1}$, Sigma) whereas by ammonium bicarbonate buffer for the negative controls ( $0 \%$ of protease activity). The activity for each sample was expressed as \% protease activity in relation to the controls. All samples were analyzed in triplicate.

\section{Antiprotease Activities}

Antiprotease activity was determined by the capacity of serum to inhibit trypsin activity (33). Briefly, $10 \mu \mathrm{L}$ of serum were incubated $(10 \mathrm{~min}, \mathrm{RT})$ with $10 \mu \mathrm{L}$ of trypsin solution $(5 \mathrm{mg}$ $\mathrm{ml}^{-1}$, Sigma) in sterile eppendorfs. After were added $100 \mu \mathrm{L}$ of ammonium bicarbonate buffer and $125 \mu \mathrm{L}$ of $2 \%$ azocasein (Sigma Aldrich) and the mixtures incubated for $2 \mathrm{~h}$ at RT. Following were added $250 \mu \mathrm{L}$ of $10 \%$ trichloroacetic acid (TCA) and the samples incubated for an additional $30 \mathrm{~min}$ at RT. The mixtures were then centrifuged $(6,000 \mathrm{~g}, 5 \mathrm{~min}), 100 \mu \mathrm{L}$ of the supernatants transferred to a flat-bottomed 96-well plate, and 100 $\mu \mathrm{L}$ of $1 \mathrm{~N} \mathrm{NaOH}$ added. The OD was read at $450 \mathrm{~nm}$ using a plate reader (100\% trypsin inhibition) was used buffer with no sample or trypsin, and for the negative controls ( $0 \%$ trypsin inhibition) was used a combination of buffer and trypsin solution. The activity for each sample was expressed as \% trypsin inhibition in relation to the controls. All samples were analyzed in triplicate.

\section{Lysozyme Activity}

Lysozyme activity was measured according to the turbidimetric method described by Espinosa Ruiz et al. (34). Twenty-five microliter of serum were placed in a flat-bottomed 96-well plate. To each well, $175 \mu \mathrm{L}$ of freeze-dried Micrococcus lysodeikticus in $10 \mathrm{mM}$ PBS, pH $6.2\left(0.3 \mathrm{mg} \mathrm{mL} \mathrm{mL}^{-1}\right.$, Sigma, UK) was added as lysozyme substrate. The reduction in absorbance at $450 \mathrm{~nm}$ was measured over $15 \mathrm{~min}$ at $3 \mathrm{~min}$ intervals at RT in a plate reader. One unit of lysozyme activity was defined as a reduction in absorbance of $0.001 \mathrm{~min}^{-1}$. The units of lysozyme present in serum were obtained from a standard curve made with hen egg white lysozyme (HEWL, Sigma, UK), and the results were expressed as $\mathrm{U}$ mg protein ${ }^{-1}$. All samples were analyzed in triplicate.

\section{Bactericidal Activity}

Bactericidal activity was determined following the method describe by Espinosa Ruiz et al. (34). Samples of $20 \mu \mathrm{L}$ of serum were added (in three replicates) to the wells of a flatbottomed 96-well plate. PBS solution was added to some wells instead of the serum as positive control. Aliquots of $20 \mathrm{Ml}$ of the previously cultured bacteria were added and the plates were incubated for $5 \mathrm{~h}$ at $25^{\circ} \mathrm{C}$. Then, $25 \mu \mathrm{L}$ of MTT $\left(1 \mathrm{~g} \mathrm{~L}^{-1}\right)$ were added to each well and the plates were newly incubated again for $10 \mathrm{~min}$ at $25^{\circ} \mathrm{C}$ to allow the formation of formazan. Plates were then centrifuged (4,500 rpm, $10 \mathrm{~min})$, and the precipitates dissolved in $200 \mu \mathrm{L}$ of DMSO. Then, $100 \mu \mathrm{L}$ from each well were 


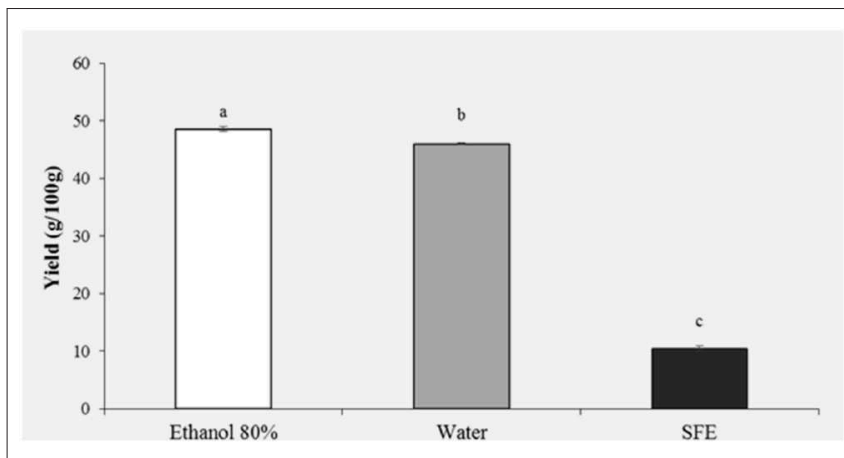

FIGURE 1 | Yield ( $\mathrm{g} / 100 \mathrm{~g}$ ) of honey bee pollen (HBP) extracts obtained with different solvents. Lowercase letters indicate significant differences between different solvents $(a, b, c: P<0.05)$.

transferred to another flat-bottom 96-well plate. The absorbance of the dissolved formazan was measured at $570 \mathrm{~nm}$. Bactericidal activity was expressed as percentage of non-viable bacteria, calculated as the difference between absorbance of surviving bacteria compared to the absorbance of bacteria in positive controls (100\%).

\section{Statistical Analysis}

Statistical differences among the groups were assessed by oneway ANOVA analyses, followed by the Tukey or Games Howell test depending on the homogeneity of the variables. Normality of the variables was confirmed by the Shapiro-Wilk test and homogeneity of variance by the Levene test. The significance level was $95 \%$ in all cases $(P<0.05)$. All the data were analyzed by the computer application SPSS for Windows ${ }^{\circledR}$ (version 20.0, SPSS Inc., Chicago, USA).

\section{RESULTS AND DISCUSSIONS}

\section{Extraction Yield of HBP}

The extraction yield obtained from HBP with different solvents (Ethanol 80\%, water and SFE) is shown in Figure 1. It was observed that the solvent with the highest extraction efficiency is ethanol $80 \%$ (48.61\%) followed by water (45.99\%). Significantly lower yields were obtained with SFE (10.47\%).

The extraction yield and antioxidant activity of plant and other natural extracts strongly depend, both qualitatively and quantitatively, on the polarity of the solvent used during extraction $(10,11)$.

Previous studies have shown that usually the highest yields are obtained with ethanol, methanol and their mixtures with water (11). Kroyer and Hegedus (7) in their study on bee pollen obtained a yield on aqueous extracts comparable to our results, instead their obtained a lower yield for ethanol extracts.

Total yield obtained from bee pollen using $\mathrm{SC}-\mathrm{CO}_{2}$ and $\mathrm{co}-$ solvent (ethanol 96\%) was higher than the one reported by $\mathrm{Xu}$ et al. (5), by applying the same pressure and temperature parameters. These authors in fact reach a maximum yield of $5,66 \%$ but without using ethanol as co-solvent. Other authors reported that SFE with $\mathrm{CO}_{2} / \mathrm{EtOH}$ could give the best

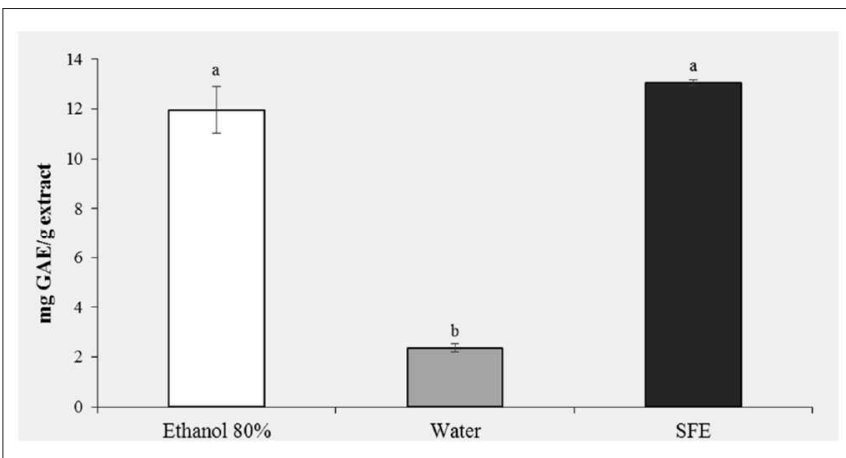

FIGURE 2 | Total phenolic content (mg GAE/g extract) of honey bee pollen (HBP) extracts obtained with different solvents. Lowercase letters indicate significant differences between different solvents ( $a, b, c: P<0.05)$.

performance, combining extraction yield, and product quality (antioxidant activity and total phenolic compounds) (35).

\section{Characterization of the Antioxidant Power of HBP}

\section{Total Polyphenols Contents}

Figure 2 shows the results of the polyphenol content. It was observed that the highest content of phenolic compounds was recorded in the pollen extract obtained with ethanol $80 \%$ (11.96 mg GAE/g) and in the extract obtained with the SFE (13.06 mg GAE/g). With regard to the ethanol extract, this result was expected, being ethanol a very efficient solvent for antioxidant extraction (18). For extracts obtained with SFE, on the other hand, a polyphenol content comparable to the ethanol extract is observed, confirming that extraction with SFE offers greater selectivity, shorter extraction times and does not use toxic organic solvents. It is important to stress how the water extract showed the significantly lowest polyphenol content (2 mg GAE/g; $P<0.05)$.

Given its eco-friendly characteristics and the absence of solvents, extraction with SFE is a suitable technique to produce extracts that can be employed for fish feed.

\section{1-Diphenyl-2-picrylhydrazyl (DPPH) Radical Scavenging Activity}

The DPPH test was used to evaluate the scavenging activity of bee pollen against free radicals.

Different values can be found in the literature regarding the activity of scavenging of bee pollen; values between 0 and $97 \%$ can be observed in relation to different species of flowers, their chemical composition and extraction with different solvents (36-39).

As shown in Figure 3, ethanol extracts of bee pollen showed high scavenging activity of free radicals with IC50 values of $0.66 \mathrm{mg} / \mathrm{ml}$, similar to those observed by Gabriele et al. (39). Extracts obtained with SFE also showed high scavenging activity $(3.12 \mathrm{mg} / \mathrm{ml})$.

\section{Reducing Power}

The antioxidant activity is improved by the reducing power, which is linked to the presence of reducing agents that, through 


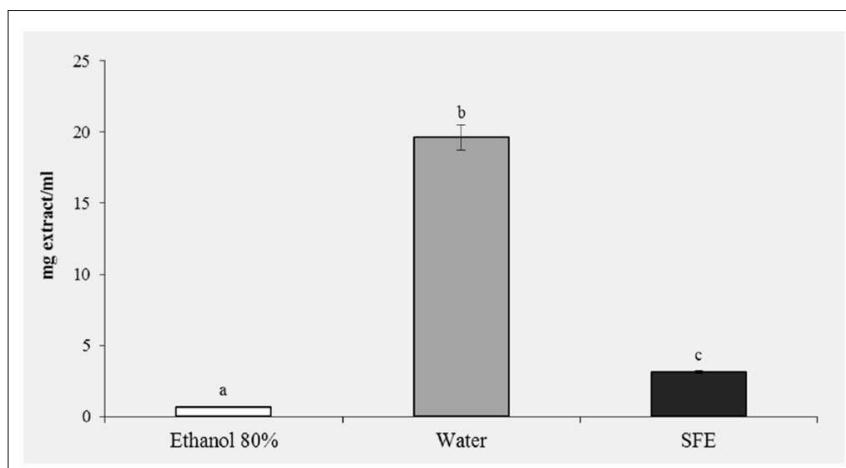

FIGURE 3 | DPPH radical scavenging activity (IC 50, $\mathrm{mg} / \mathrm{mL}$ ) of honey bee pollen (HBP) extracts obtained with different solvents. Lowercase letters indicate significant differences between different solvents $(\mathrm{a}, \mathrm{b}, \mathrm{c}: P<0.05)$.

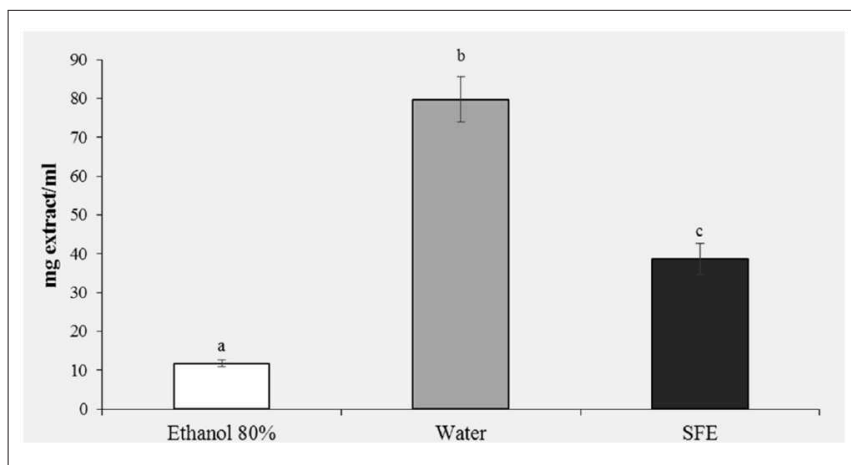

FIGURE 4 | Reducing power (EC50, mg/ml) of honey bee pollen (HBP) extracts obtained with different solvents. Lowercase letters indicate significant differences between different solvents $(a, b, c: P<0.05)$.

the donation of a hydrogen atom to free radicals, convert them into stable compounds, breaking the oxidizing chain reaction $(10,40)$. Through the power reduction assay, the reducing components of a sample can be evaluated directly by measuring the reduction of $\mathrm{Fe}^{3+}$ in $\mathrm{Fe}^{2+}$.

In the reducing power assay, the results are expressed as EC50/mg extract, where EC50 value $\left(\mathrm{mg} \mathrm{mL}^{-1}\right)$ is the effective concentration of the extract at which the absorbance was 0.5 . The results presented in Figure 4 confirm the previous results of the DPPH (Figure 3) and polyphenols (Figure 2); in fact, a greater reducing activity is observed for the samples extracted with ethanol 80\% (11.76) and SFE (38.68).

\section{Serum Immune Parameters Determined in Sparus aurata}

At the end of the feeding period, no statistical differences were found among groups for final weight $(336 \pm 11.35 \mathrm{~g})$ and FCR $(2.3 \pm 0.7)$. Fish fed with both diets P5 and P10 showed some inhibitory effects in the immune response, such a decrease of serum peroxidase (Figure 5A) and lysozyme activities (Figure 5D) respect to the control groups $(p<0.05)$. It is known that the peroxidase enzyme is present in hemocyte granules (41), contributing to the respiratory that involves the production of oxygen metabolites (such as superoxide anion, hydrogen peroxide, and intermediate compounds with high bactericidal activity) (42). After the phagocytosis of microorganisms and other microparticles follows a degranulation process by which these radicals are discharged into the phagosome (43). A reduced peroxidase activity may affect the ability to neutralize pathogens (43), suggesting that the inclusion of 5 and $10 \%$ of bee pollen in the diet of sea bream may impair defense capacity. Additionally, lysozyme is a bactericidal enzyme present in the lysosome with an important defense role due to its ability to hydrolyze the components of the bacterial walls $(44,45)$. The enzyme catalysis the cleavage of $\beta-1-4$ bonds between $\mathrm{N}$-acetylglucosamine and $\mathrm{N}$ acetylmuramic acid of bacterial cell wall peptidoglycan, thereby causing bacteriolysis and preventing the growth of bacteria (2, 46). Lysozyme is also known to display anti-viral and antiinflammatory properties, as well as to activate the complement system and phagocytes by acting like an opsonin (2, 47, 48). During phagocytosis, lysozyme is secreted by hemocytes in the hemolymph, thus inactivating pathogens.

In a recent study, Panettieri et al. (15) highlighted how the use of different inclusion levels of HBP in the diet for meager juveniles led to a worsening of fish growth and nutrients digestibility, along with histological alterations of medium intestine that became more and more severe as the HBP inclusion levels in the diet increased. Such results were supported by immunohistochemistry, hepatic biomolecular markers and blood biochemical analyses. In particular, immunohistochemical detection of TNF- $\alpha$ in medium intestine showed the presence of TNF- $\alpha+$ cells in the lamina propria and submucosa of bee pollen treated fish, that resulted in accordance with the increased level of the TNF- $\alpha$ protein detected by immunoblotting in the liver. The high hepatic level of HSP70 $(p<0.05)$ in fish fed the diet with the highest inclusion level of HBP (4\%) and the linear decrease of total serum protein levels in fish fed the HBP containing diets confirmed the stress situation. The authors attributed these negative effects to the ultrastructure of the bee pollen grains walls that make the bioactive substances unavailable and can irritate the intestine of a carnivorous fish. In particular, the pollen cell walls are composed by stratified concentric layers. The outermost layer is a semi-solid coating composed of neutral lipids, hydrocarbons, terpenoids, and carotenoid pigments. Inside this wall is the exine a matrix of complex carbohydrate, sporopollenin. The exine greatly resists to monogastric digestion and its structure is similar to lignin. These characteristics of raw pollen may make it irritant for the intestinal mucosa and make the bioactive substances at least partially unavailable for carnivorous fish. These aspects could explain the decrease of serum peroxidase and lysozyme activities in P5 and P10 groups compared to the control group.

There are few studies on the use of bee pollen as feed in aquaculture to improve the immunity and protection of fish against fish pathogens. Geay et al. (49) observed that lysozyme levels resulted significantly decreased in Dicentrarchus labrax fed on a plant-based diet respect to a diet containing fishmeal. An interesting note is that the present study indicates an improvement in lysozyme levels with the inclusion of HBP extract $(0.5$ and $1 \%)$ in the $S$. aurata diet (Figure 5D). This 

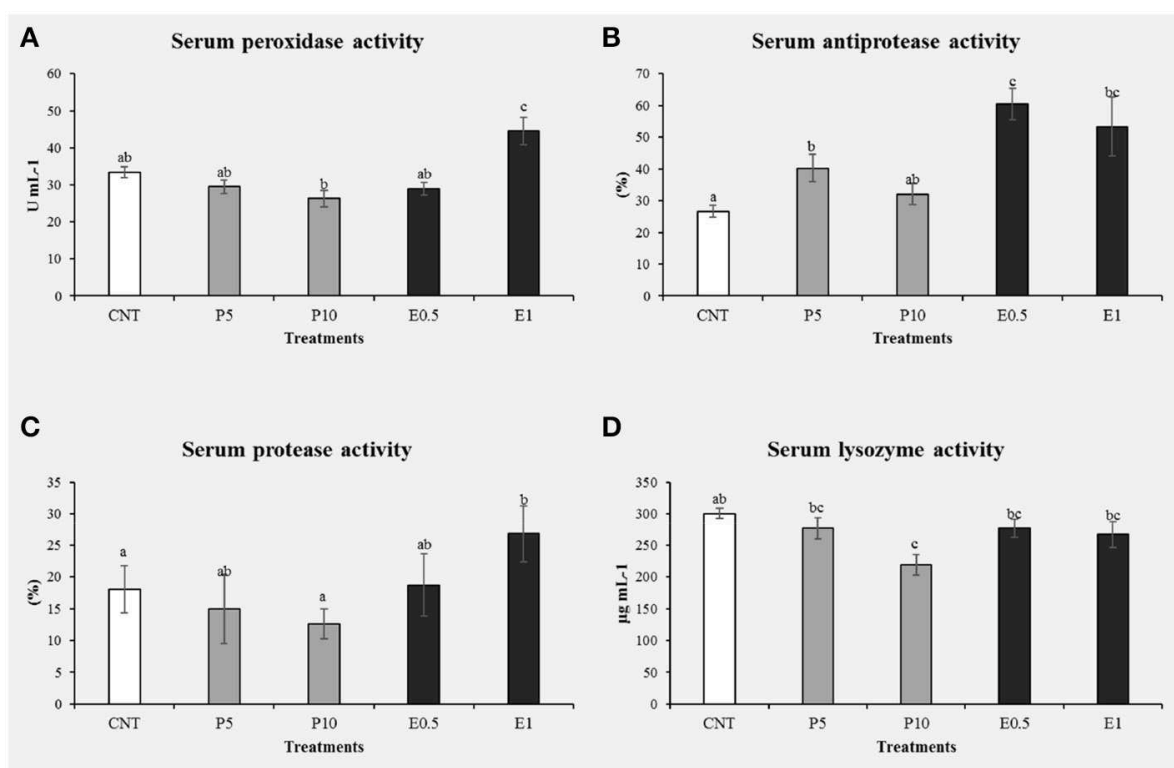

D

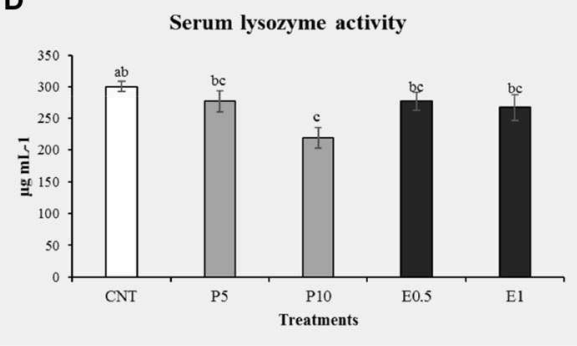

FIGURE 5 | Immune related parameters determined in the serum of S. aurata fed with honey bee pollen (HBP) and its SFE extract (CNT: control, P5: pollen 5\%, P10: pollen 10\%, E0.5: SFE 0.5\% and E1: SFE 1\%): peroxidase activity (U mg prot-1) (A), antiprotease activity (\%) (B), protease activity (\%) (C), and lysozyme activity (U mg prot-1) (D). Values are the mean \pm SEM $(n=9)$. Statistical differences $(P<0.05)$ between groups are indicated by different letters.

difference could be related to the total substitution of fishmeal with vegetable proteins in the case of the study by Geay et al. (49), or may indicate that the percentages of pollen inclusion (5 and $10 \%$ ) used in our study are too high, as they may have interrupted the amino acid profile of diets. Likewise, in the study carried out by Abd-El-Rhman (50) propolis-ethanolic-extract and crude propolis significantly increased the serum lysozyme activity, so it stimulated the immune response in Nile tilapia. The increased lysozyme activity has been reported after supplementing the fish-feed, with non-specific immunostimulants as a mixture of propolis and herba epimedii extracts (51). For this reason, decreased lysozyme activity may suggest immunosuppression in animals, which may lower resistance to pathogenic bacteria (34).

The protease and antiprotease activities were evaluated in serum from sea bream fed the different diets for 1 month (Figures 5B,C). Specimens fed P5, E0.5, and E1 showed significantly increased their antiprotease activities with respect to the control groups $(p<0.05)$. On the other hand, animals fed the $\mathrm{E} 1$ showed the protease activity significantly increased with respect to the control groups $(p<0.05)$.

Protease and antiprotease activities activate and improve the development of several immune components such as antimicrobial peptides, complement, and immunoglobulins (52-55). In particular, proteases degrade proteins into either polypeptides or amino acids (56), being principally carried out to reduce the pathogenicity of bacteria and parasites.

Antiproteases, instead, are protease inhibitors that are known to be involved in phagocytosis, coagulation, complement activation and fibrinolysis $(55,56)$, and moreover, contributes to the innate immunity of animals through its bactericidal and antiinflammatory properties (57), that restrict the ability of bacteria to invade and grow in fish, by inhibiting their extracellular enzymes $(2,58)$.

These results indicate that the pollen extract activated the immune system of sea bream, in accordance with previous studies in which the immunostimulant efficacy of plants, certain parts of the same or even their extracts used in feeding tests on fish has been demonstrated $(17,51,59-61)$.

\section{Bactericidal Activity}

Another objective of the present study was to study the effects of the inclusion of pollen in the $S$. aurata diet against two opportunistic pathogenic bacteria, $V$. harveyii and $V$. anguillarum, which were chosen since they are responsible for infections affecting a variety of marine animals, including fish, crustaceans, mollusks, and cetaceans and also humans.

Bactericidal activity was evaluated in serum from fish fed the different diets for 1 month (Figures 6A,B). Regarding the bactericidal activity against $V$. harveyii, all the specimens fed the different doses showed their serum bactericidal activity significantly increased with respect to the control groups $(p<$ 0.05). On the other hand, only the fish fed with P5 diet showed it bactericidal activity against $V$. anguillarum significantly increased with respect to the control and groups $(p<0.05)$. In addition, Vibrionaceae represents the main cause of mortality in farmed marine species $(62,63)$. With regard to this, past results show that Gram-positive marine bacteria are usually more susceptible to herbal extracts than Gram-negative marine Vibrionaceae. The results obtained in this study reflect those of similar studies conducted by other authors $(14,50,64)$. In previous works honey bee pollen or propolis extracts inclusion in the diet reduced the mortality among A. hydrophila challenged fish $(50,64)$. This benefit is certainly ascribed to the enhanced 

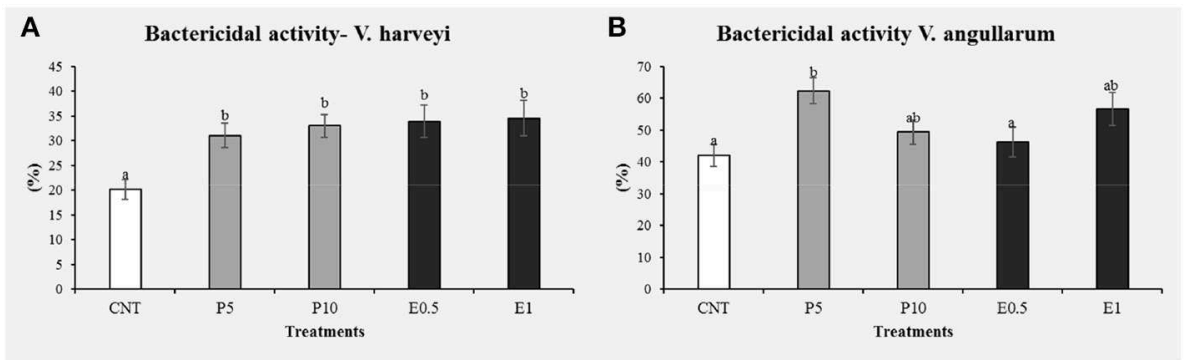

FIGURE 6 | Bactericidal activity against Vibrio harveyi (A) and Vibrio anguillarum (B) determined in the serum of S. aurata fed with pollen and SFE extract from pollen (CNT: control, P5: pollen 5\%, P10: pollen 10\%, E0.5: extract 0.5\% and E1: extract 1\%). Values are the mean \pm SEM $(n=9)$. Statistical differences $(P<0.05)$ between groups are indicated by different letters.

non-specific immune responses and the antioxidant effects of pollen or propolis extract through its constituent flavonoids, which have antibacterial activity (65).

Therefore, we conclude that pollen SFE at $1 \%$ seems to be the best option as supplement in the diet of farmed fish, acting as immunostimulant and antioxidant, able to reinforce the humoral response.

\section{CONCLUSIONS}

The supplementation with natural compounds has proved to be a useful tool in aquaculture industry and for this reason, green techniques as SFE, able to reduce the utilization of solvent and to produce extract suitable for nutritional purposes, are encouraged. In the present study, the inclusion of pollen extract in the S. aurata diet improved the humoral immunity, as demonstrated by the most common markers related to immunity in fish.

\section{DATA AVAILABILITY STATEMENT}

All datasets generated for this study are included in the article/supplementary files.

\section{REFERENCES}

1. García Beltrán JM, Espinosa C, Guardiola FA, Esteban MÁ. Dietary dehydrated lemon peel improves the immune but not the antioxidant status of gilthead seabream (Sparus aurata L.). Fish Shellfish Immunol. (2017) 64:42636. doi: 10.1016/j.fsi.2017.03.042

2. Bulfon C, Volpatti D, Galeotti M. Current research on the use of plant-derived products in farmed fish. Aquac Res. (2015) 46:513-51. doi: 10.1111/are.12238

3. Reverter M, Bontemps N, Lecchini D, Banaigs B, Sasal P. Use of plant extracts in fish aquaculture as an alternative to chemotherapy: current status and future perspectives. Aquaculture. (2014) 433:50-61. doi: 10.1016/j.aquaculture.2014.05.048

4. Harikrishnan R, Balasundaram C, Heo MS. Impact of plant products on innate and adaptive immune system of cultured finfish and shellfish. Aquaculture. (2011) 317:1-15. doi: 10.1016/j.aquaculture.2011.03.039

5. Xu X, Sun L, Dong J, Zhang H. Breaking the cells of rape bee pollen and consecutive extraction of functional oil with supercritical carbon dioxide. Innov Food Sci Emerg Technol. (2009) 10:42-6. doi: 10.1016/j.ifset.2008. 08.004

\section{ETHICS STATEMENT}

The animal study was reviewed and approved by Italian Ministry of Health, authorization n. 651/2017-PR.

\section{AUTHOR CONTRIBUTIONS}

GP and FB contributed to the conception of the experimental design for the feeding trial with honey bee pollen. CMM and AS contributed to the conception of the experimental design for the alternative methods of extraction, assessment of the antioxidants profile, and immune-related parameters in fish. VP and GP conducted the feeding trials and performed the samples collection. GR and RA performed the extraction by supercritical fluid extraction and the determination of the antioxidants and fatty acids profile of the extracts. CER and MM performed the blood analyses and bactericidal activities and performed the statistical analysis. CMM, GP, AS, and FB supported the acquisition and interpretation of data. VP, RA, MM, CER, and GR drafted the article. CMM, GP, AS, and FB revised and finalized the article. All the authors gave final approval to the manuscript and any revised version submitted.

6. Ares AM, Valverde S, Bernal JL, Nozal MJ, Bernal J. Extraction and determination of bioactive compounds from bee pollen. J Pharm Biomed Anal. (2018) 147:110-24. doi: 10.1016/j.jpba.2017.08.009

7. Kroyer G, Hegedus N. Evaluation of bioactive properties of pollen extracts as functional dietary food supplement. Innov Food Sci Emerg Technol. (2001) 2:171-4. doi: 10.1016/S1466-8564(01)00039-X

8. Conte G, Benelli G, Serra A, Signorini F, Bientinesi M, Nicolella C, et al. Lipid characterization of chestnut and willow honeybee-collected pollen: impact of freeze-drying and microwave-assisted drying. J Food Compos Anal. (2017) 55:12-9. doi: 10.1016/j.jfca.2016.11.001

9. Trabelsi N, Megdiche W, Ksouri R, Falleh H, Oueslati S, Soumaya B, et al. Solvent effects on phenolic contents and biological activities of the halophyte Limoniastrum monopetalum leaves. LWT Food Sci Technol. (2010) 43:632-9. doi: 10.1016/j.lwt.2009.11.003

10. Messina CM, Renda G, Laudicella V, Trepos R, Fauchon M, Hellio C, et al. From ecology to biotechnology, study of the defense strategies of algae and halophytes (from Trapani Saltworks, NW Sicily) with a focus on antioxidants and antimicrobial properties. Int J Mol Sci. (2019) 20:881. doi: 10.3390/ijms20040881 
11. Franco D, Sineiro J, Rubilar M, Sánchez M, Jerez M, Pinelo $M$, et al. Polyphenols from plant materials: extraction and antioxidant power. Electron J Environ Agric Food Chem. (2008) 7:3210-6. Available online at: http://www. theunderground.at/Matura/BiCPChMatura/PCh/schule/index.pdf

12. Wang J, Li S, Wang Q, Xin B, Wang H. Trophic effect of bee pollen on small intestine in broiler chickens. J Med Food. (2007) 10:276-80. doi: 10.1089/jmf.2006.215

13. Attia YA, Al-Hanoun A, Tag El- Din AE, Bovera F, Shewika YE. Effect of bee pollen levels on productive, reproductive and blood traits of NZW rabbits. J Anim Physiol Anim Nutr. (2011) 95:294-303. doi: 10.1111/j.1439-0396.2010.01054.x

14. El-Asely AM, Abbass AA, Austin B. Honey bee pollen improves growth, immunity and protection of Nile tilapia (Oreochromis niloticus) against infection with Aeromonas hydrophila. Fish Shellfish Immunol. (2014) 40:5006. doi: 10.1016/j.fsi.2014.07.017

15. Panettieri V, Chatzifotis S, Messina CM, Olivotto I, Manuguerra S, Randazzo $\mathrm{B}$, et al. Honey bee pollen in meagre (Argyrosomus regius) juveniles diets : effects on growth, diet digestibility, intestinal traits and biochemical markers related to health and stress. Animals. (2020) 10:231. doi: 10.3390/ani10020231

16. Esteban ÁM. An overview of the immunological defenses in fish skin. ISRN Immunol. (2012) 2012:1-29. doi: 10.5402/2012/853470

17. Mansour AT, Miao L, Espinosa C, García-Beltrán JM, Ceballos Francisco DC, Esteban MÁ. Effects of dietary inclusion of Moringa oleifera leaves on growth and some systemic and mucosal immune parameters of seabream. Fish Physiol Biochem. (2018) 44:1223-40. doi: 10.1007/s10695-018-0515-Z

18. Messina CM, Troia A, Arena R, Manuguerra S, Ioannou T, Curcuraci E, et al. Species-specific antioxidant power and bioactive properties of the extracts obtained from wild Mediterranean Calendula Spp. Appl Sci. (2019) 9:4627. doi: 10.3390/app9214627

19. Gharbi S, Renda G, La Barbera L, Amri M, Messina CM, Santulli A. Tunisian tomato by-products, as a potential source of natural bioactive compounds. Nat Prod Res. (2017) 31:626-31. doi: 10.1080/14786419.2016.1209671

20. Fish WW, Perkins-Veazie P, Collins JK. A quantitative assay for lycopene that utilizes reduced volumes of organic solvents. J Food Compos Anal. (2002) 15:309-17. doi: 10.1006/jfca.2002.1069

21. Musa KH, Abdullah A, Jusoh K, Subramaniam V. Antioxidant activity of pink-flesh guava (Psidium guajava L.): effect of extraction techniques and solvents. Food Anal Methods. (2011) 4:100-7. doi: 10.1007/s12161-0109139-3

22. Messina CM, Manuguerra S, Catalano G, Arena R, Cocchi M, Morghese M, et al. Green biotechnology for valorisation of residual biomasses in nutraceutic sector: characterization and extraction of bioactive compounds from grape pomace and evaluation of the protective effects in vitro. Nat Prod Res. (2019) 6:1-6. doi: 10.1080/14786419.2019.1619727

23. Oki T, Masuda M, Furuta S, Nishiba Y, Terahara N, Suda I. Involvement of anthocyanins and other phenolic compounds in radical-scavenging activity of purple-fleshed sweet potato cultivars. J Food Sci. (2002) 67:1752-6. doi: 10.1111/j.1365-2621.2002.tb08718.x

24. Bernatoniene J, Masteikova R, Davalgiene J, Peciura R, Gauryliene R, Bernatoniene $\mathrm{R}$, et al. Topical application of calendula officinalis (L.): formulation and evaluation of hydrophilic cream with antioxidant activity. J Med Plants Res. (2011) 5:868-77. Available online at: https://pdfs. semanticscholar.org/0094/bf5773b9983b37c696ead7f648dbb660c030.pdf

25. Manuguerra S, Caccamo L, Mancuso M, Arena R, Rappazzo AC, Genovese $\mathrm{L}$, et al. The antioxidant power of horseradish, Armoracia rusticana, underlies antimicrobial and antiradical effects, exerted in vitro. Nat Prod Res. (2018) 1-4. doi: 10.1080/14786419.2018.1517121

26. Yeddes N, Chérif J, Guyot S, Sotin H, Ayadi M, Yeddes N, et al. Comparative study of antioxidant power, polyphenols, flavonoids and betacyanins of the peel and pulp of three tunisian opuntia forms. Antioxidants. (2013) 2:37-51. doi: $10.3390 /$ antiox 2020037

27. Oyaizu M. Studies on product of browning reaction: antioxidative activities of products of browning reaction prepared from glucosamine. Jap J Nutr. (1986) 307-15. doi: 10.5264/eiyogakuzashi.44.307

28. Falleh H, Ksouri R, Medini F, Guyot S, Abdelly C, Magné C. Antioxidant activity and phenolic composition of the medicinal and edible halophyte Mesembryanthemum edule L. Ind Crops Prod. (2011) 34:1066-71. doi: 10.1016/j.indcrop.2011.03.018
29. Gómez-Requeni P, Mingarro M, Calduch-Giner JA, Médale F, Martin SAM, Houlihan DF, et al. Protein growth performance, amino acid utilisation and somatotropic axis responsiveness to fish meal replacement by plant protein sources in gilthead sea bream (Sparus aurata). Aquaculture. (2004) 232:493510. doi: 10.1016/S0044-8486(03)00532-5

30. Peres $\mathrm{H}$, Oliva-Teles A. The optimum dietary essential amino acid profile for gilthead seabream (Sparus aurata) juveniles. Aquaculture. (2009) 296:81-6. doi: 10.1016/j.aquaculture.2009.04.046

31. Quade MJ, Roth JA. A rapid, direct assay to measure degranulation of bovine neutrophil primary granules. Vet Immunol Immunopathol. (1997) 58:239-48. doi: 10.1016/S0165-2427(97)00048-2

32. Ross N, Firth K, Wang A, Burka J, Johnson S. Changes in hydrolytic enzyme activities of naïve Atlantic salmon Salmo salar skin mucus due to infection with the salmon louse Lepeophtheirus salmonis and cortisol implantation. Dis Aquat Organ. (2000) 41:43-51. doi: 10.3354/dao041043

33. Hanif A, Bakopoulos V, Dimitriadis GJ. Maternal transfer of humoral specific and non-specific immune parameters to sea bream (Sparus aurata) larvae. Fish Shellfish Immunol. (2004) 17:411-35. doi: 10.1016/j.fsi.2004.04.013

34. Espinosa Ruiz C, Morghese M, Renda G, Gugliandolo C, Esteban MA, Santulli A, et al. Effects of BDE-47 exposure on immune-related parameters of Mytilus galloprovincialis. Aquat Toxicol. (2019) 215:105266. doi: 10.1016/j.aquatox.2019.105266

35. Castro-Vargas HI, Rodríguez-Varela LI, Ferreira SRS, Parada-Alfonso F, Extraction of phenolic fraction from guava seeds (Psidium guajava L.) using supercritical carbon dioxide and co-solvents. J Supercrit Fluids. (2010) 51:31924. doi: 10.1016/j.supflu.2009.10.012

36. Silva TMS, Camara CA, da Silva Lins AC, Maria Barbosa-Filho J, da Silva EMS, Freitas BM, et al. Chemical composition and free radical scavenging activity of pollen loads from stingless bee Melipona subnitida Ducke. J Food Compos Anal. (2006) 19:507-11. doi: 10.1016/j.jfca.2005.12.011

37. LeBlanc BW, Davis OK, Boue S, DeLucca A, Deeby T. Antioxidant activity of Sonoran Desert bee pollen. Food Chem. (2009) 115:1299-305. doi: 10.1016/j.foodchem.2009.01.055

38. Basuny AM, Arafat SM, Soliman HM. Chemical analysis of olive and palm pollen: Antioxidant and antimicrobial activation properties. Wudpecker J Food Technol. (2013) 1:14-21. Available online at: https://pdfs. semanticscholar.org/b2f2/c16e7aebd8ee43c419b935371b5e56e8d071.pdf

39. Gabriele M, Parri E, Felicioli A, Sagona S, Pozzo L, Biondi C, et al. Phytochemical composition and antioxidant activity of Tuscan bee pollen of different botanic origins. Ital J Food Sci. (2015) 27:120-31. doi: 10.14674/1120-1770/ijfs.v191

40. Bayar N, Kriaa M, Kammoun R. Extraction and characterization of three polysaccharides extracted from Opuntia ficus indica cladodes. Int $\mathrm{J}$ Biol Macromol. (2016) 92:441-50. doi: 10.1016/j.ijbiomac.2016.07.042

41. Carballal MJ, López C, Azevedo C, Villalba A. Enzymes Involved in Defense Functions of Hemocytes of Mussel Mytilus galloprovincialis. J Invertebr Pathol. (1997) 70:96-105. doi: 10.1006/jipa.1997.4670

42. Pruzzo C, Gallo G, Canesi L. Persistance of vibrios in marine bivalves: the role of interactions with haemolyph components. Environ Microbiol. (2005) 7:761-72. doi: 10.1111/j.1462-2920.2005.00792.x

43. Klebanoff SJ. Microbicidal mechanisms, oxygen-dependent. Encycl Immunol. (1998) 1713-8. doi: 10.1006/rwei.1999.0435

44. Cheng TC, Rodrick GE. Identification and characterization of lysozyme from the hemolymph of the soft-shelled clam, Mya arenaria. Biol Bull. (1974) 147:311-20. doi: 10.2307/1540451

45. Cheng TC. The role of lysosomes in molluscan inflamation. Am Zool. (1983) 23:129-44. doi: 10.1093/icb/23.1.129

46. Cuvillier-Hot V, Boidin-Wichlacz C, Tasiemski A. Polychaetes as annelid models to study ecoimmunology of marine organisms. J Mar Sci Technol. (2014) 22:9-14. doi: 10.6119/JMST-013-0718-1

47. Magnadóttir B. Innate immunity of fish (overview). Fish Shellfish Immunol. (2006) 20:137-51. doi: 10.1016/j.fsi.2004.09.006

48. Saurabh S, Sahoo PK. Lysozyme: an important defence molecule of fish innate immune system. Aquac Res. (2008) 39:223-39. doi: 10.1111/j.1365-2109.2007.01883.x

49. Geay F, Ferraresso S, Zambonino-Infante JL, Bargelloni L, Quentel $C$, Vandeputte $M$, et al. Effects of the total replacement of fishbased diet with plant-based diet on the hepatic transcriptome of two 
European sea bass (Dicentrarchus labrax) half-sibfamilies showing different growth rates with the plant-based diet. BMC Genomics. (2011) 12:522. doi: 10.1186/1471-2164-12-522

50. Abd-El-Rhman AMM. Antagonism of Aeromonas hydrophila by propolis and its effect on the performance of Nile tilapia, Oreochromis niloticus. Fish Shellfish Immunol. (2009) 27:454-9. doi: 10.1016/j.fsi.2009.06.015

51. Chu WH. Adjuvant effect of propolis on immunisation by inactivated Aeromonas hydrophila in carp (Carassius auratus gibelio). Fish Shellfish Immunol. (2006) 21:113-7. doi: 10.1016/j.fsi.2005.10.002

52. Yoshikawa $T$, Imada $T$, Nakakubo $H$, Nakamura $N$, Naito, K. Rat mast cell protease-I enhances immunoglobulin $\mathrm{E}$ production by mouse B cells stimulated with interleukin-4. Immunology. (2001) 104:333-40. doi: 10.1046/j.1365-2567.2001.01320.x

53. Cho JH, Park IY, Kim HS, Lee WT, Kim MS, Kim SC. Cathepsin D produces antimicrobial peptide parasin I from histone $\mathrm{H} 2 \mathrm{~A}$ in the skin mucosa of fish. FASEB J. (2002) 16:429-31. doi: 10.1096/fj.01-0736fje

54. Cho JH, Park IY, Kim MS, Kim SC. Matrix metalloproteinase 2 is involved in the regulation of the antimicrobial peptide parasin I production in catfish skin mucosa. FEBS Lett. (2002) 531:459-63. doi: 10.1016/S0014-5793(02)03584-6

55. Khan MS, Goswami U, Rojatkar SR, Khan MI. A serine protease inhibitor from hemolymph of green mussel, Perna viridis. Bioorg Med Chem Lett. (2008) 18:3963-7. doi: 10.1016/j.bmcl.2008.06.010

56. Walker B, Lynas JF. Strategies for the inhibition of serine proteases. Cell Mol Life Sci. (2001) 58:596-624. doi: 10.1007/PL00000884

57. Jollès P, Jollès J. What's new in lysozyme research? Mol Cell Biochem. (1984) 63:165-89. doi: 10.1007/BF00285225

58. Ellis AE. Innate host defense mechanisms of fish against viruses and bacteria. Dev Comp Immunol. (2001) 25:827-39. doi: 10.1016/S0145-305X(01)00038-6

59. Christybapita D, Divyagnaneswari M, Dinakaran Michael R. Oral administration of Eclipta alba leaf aqueous extract enhances the non-specific immune responses and disease resistance of Oreochromis mossambicus. Fish Shellfish Immunol. (2007) 23:840-52. doi: 10.1016/j.fsi.2007.03.010
60. Yin G, Ardó L, Thompson KD, Adams A, Jeney Z, Jeney G. Chinese herbs (Astragalus radix and Ganoderma lucidum) enhance immune response of carp, Cyprinus carpio, and protection against Aeromonas hydrophila. Fish Shellfish Immunol. (2009) 26:140-5. doi: 10.1016/j.fsi.2008.08.015

61. Zhang G, Gong S, Yu D, Yuan H. Propolis and Herba Epimedii extracts enhance the non-specific immune response and disease resistance of Chinese sucker, Myxocyprinus asiaticus. Fish Shellfish Immunol. (2009) 26:467-72. doi: 10.1016/j.fsi.2009.01.011

62. Nguyen A, Jacq A. Small RNAs in the Vibrionaceae : an ocean still to be explored. Wiley Interdiscip Rev RNA. (2014) 5:381-92. doi: 10.1002/wrna.1218

63. Beltrán JMG, Espinosa C, Guardiola FA, Esteban MÁ. In vitro effects of Origanum vulgare leaf extracts on gilthead seabream (Sparus aurata L.) leucocytes, cytotoxic, bactericidal and antioxidant activities. Fish Shellfish Immunol. (2018) 79:1-10. doi: 10.1016/j.fsi.2018.05.005

64. Wu CC, Liu CH, Chang YP, Hsieh SL. Effects of hot-water extract of Toona sinensis on immune response and resistance to Aeromonas hydrophila in Oreochromis mossambicus. Fish Shellfish Immunol. (2010) 29:258-63. doi: 10.1016/j.fsi.2010.04.021

65. Pietta PG. Flavonoids as antioxidants. J Nat Prod. (2000) 63:1035-42. doi: $10.1021 /$ np 9904509

Conflict of Interest: The authors declare that the research was conducted in the absence of any commercial or financial relationships that could be construed as a potential conflict of interest.

Copyright (C) 2020 Messina, Panettieri, Arena, Renda, Espinosa Ruiz, Morghese, Piccolo, Santulli and Bovera. This is an open-access article distributed under the terms of the Creative Commons Attribution License (CC BY). The use, distribution or reproduction in other forums is permitted, provided the original author(s) and the copyright owner(s) are credited and that the original publication in this journal is cited, in accordance with accepted academic practice. No use, distribution or reproduction is permitted which does not comply with these terms. 